\title{
Ny handlingsplan for forebygging av selvmord og selvskading - en kommentar
}

\author{
Ved Erlend Mork
}

\begin{abstract}
Etter at Norge var ett av de første landene som utarbeidet en nasjonal strategi på 90-tallet, har vi ikke hatt en helhetlig nasjonal strategiplan for forebygging av selvmord i Norge siden 2002. Det er derfor en viktig milepæl når Handlingsplan for forebygging av selvmord og selvskading 2014-2017 nå foreligger. En kort oppsummering av handlingsplanens oppbygging og innhold presenteres. Forfatteren peker på den avgjørende betydningen av hvilke valg og prioriteringer som blir gjort i forhold til nye tiltak i planperioden, og at disse tiltakene gjennomføres med tilstrekkelig dybde og forankring. Fire områder presenteres og diskuteres med tanke på hvordan tiltakene kan utvides eller utdypes:

a) tiltak for å senke terskelen for å søke hjelp, b) tiltak for å fremme psykisk helse og mestring i skolen, c) tiltak for bedre tilgang til kunnskapsbasert behandling og d) tiltak for bedre monitorering av selvmordsatferd og selvskading.
\end{abstract}

Norway was among the first countries to develop a national strategy for suicide prevention in the 90's. However, since 2002 Norway has not had a comprehensive national action plan for suicide prevention. Thus, an important milestone was reached when the action plan for prevention of suicide and self-harm (2014-2017) was published earlier this year. This paper provides a short overview of the structure and content of the action plan. The author underlines the importance of what decisions will be made with regard to new initiatives and that these initiatives are carried out with sufficient depth and anchoring. Four areas are presented and discussed in terms of how the initiatives can be expanded or elaborated:

a) initiatives to lower the threshold for seeking help, b) initiatives to promote mental health and coping in school,

c) initiatives to improve access to knowledge-based treatments and d) initiatives for better monitoring of suicidal behaviour and self-harm.
Norge var tidlig ute med å utarbeide et Nasjonalt program for forebygging av selvmord (Helsedirektoratet, 1993). Handlingsplan mot selvmord ble iverksatt fra midten av 90-tallet og etterfulgt av 0ppfølgingsprosjektet - Tiltak mot selvmord 2000-2002 (Reinholdt, 2000; Statens helsetilsyn, 1995). På tross av flere forsøk har vi imidlertid ikke hatt en helhetlig nasjonal plan for det selvmordsforebyggende arbeidet i Norge siden 2002.

For meg, som har ledet en arbeidsgruppe som utarbeidet et utkast til en ny handlingsplan i 2012, og for det forebyggende arbeidet i Norge, er det derfor en milepæl når Handlingsplan for forebygging av selvmord og selvskading 2014-2017 nå foreligger (Helsedirektoratet, 2014).

Planen skisserer pågående arbeid og nye tiltak. Jeg vil i denne artikkelen først kort presentere planens oppbygning og innhold for deretter å argumentere for at hvis planen skal få den ønskede effekt er det viktig at det satses med tyngde på noen tiltak som utdypes og forankres tydelig i det videre arbeidet.

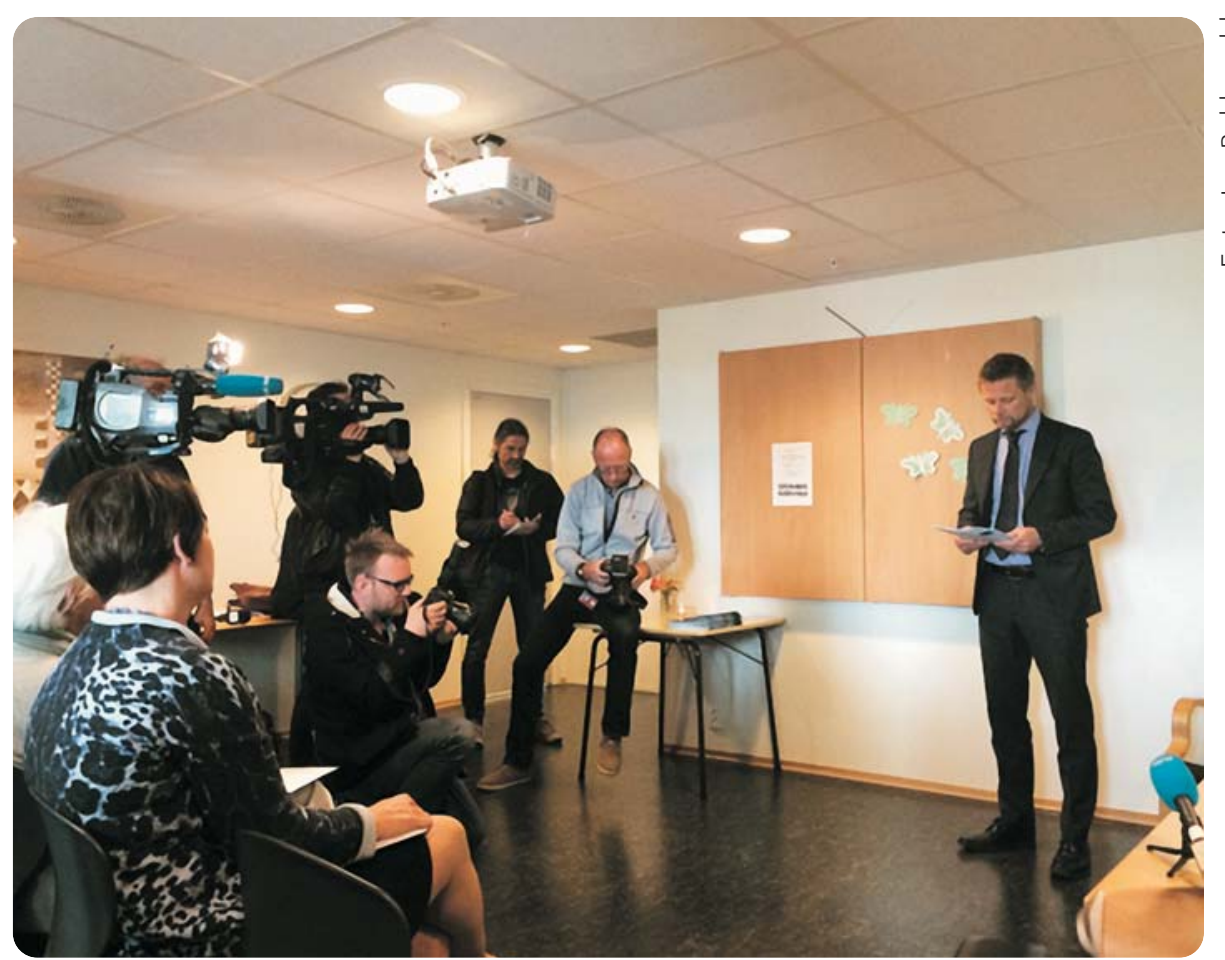

Handlingsplanen ble lansert 30. april i år av helseminister Bent Høie.
Handlingsplan for forebygging av selvmord og selvskading 2014-2017 utgitt av Helsedirektoratet ble lansert 30. april i år av helse- og omsorgsminister Bent Høie. Det overordnede målet for handlingsplanen er å redusere omfanget av selvmord og selvskading i befolkningen. I plandokumentets Del 1: Status og utfordringsbildet beskrives omfanget av selvmord, selvmordsforsøk og selvskading i Norge, og det gis en kort gjennomgang av risiko- og beskyttelsesfaktorer. Det fremgår av denne oversikten at selvmordsraten i Norge har vært mer eller mindre uendret de siste 15 årene. Det er derfor gode argumenter for en forsterket selvmordsforebyggende innsats. Oversikten viser også at omfanget av selvskading, særlig blant unge, er høyt (Muehlenkamp, Claes, Havertape, \&t Plener, 2012; Tormoen, Rossow, Larsson, \&t Mehlum, 2012). Nytt fra tidligere strategier er at reduksjon av omfanget av (ikke-suicidal) selvskading er tatt inn som et eksplisitt mål i handlingsplanen. Denne presiseringen gir er et tydelig signal om at selvskading skal prioriteres i det forebyggende arbeidet. 
Planens Del II: Pågående arbeid og tiltak i planperioden 2014-2017 beskriver fem delmål: 1) God psykisk helse og mestring i befolkningen, 2) redusert forekomst av selvmord og selvskading i risikogrupper, 3) god oppfølging og ivaretakelse av etterlatte, pårørende og andre berørte, 4) et kunnskapsbasert tjenesteapparat og 5) kunnskapsbaserte strategier og tiltak. Under hvert delmål beskrives først pågående arbeid. Selv om vi har stått uten en handlingsplan det siste tiåret, har nasjonale og regionale forskningsog kompetansemiljøer vært i funksjon, og dette reflekteres også gjennom en rekke pågående tiltak som skal videreføres i planperioden. Oversikten over pågående arbeid innenfor ulike samfunnssektorer og på ulike forebyggingsnivåer viser noe av bredden i feltet, samtidig som det synliggjør de sammensatte utfordringene som ligger i å forebygge selvmord og selvskading. Arbeidet med reduksjon av tilgjengeligheten av selvmordsmetoder og samarbeidet med pressen om ansvarlig medieomtale av selvmord er eksempler på slikt pågående arbeid som har god dokumentasjon for selvmordsforebyggende effekt, og som det er viktig at videreføres.

I tillegg til pågående arbeid beskriver planen totalt 29 nye tiltak innen de fem delmålene. Disse tiltakene forholder seg til flere innsatsområder; fra tiltak rettet mot spesifikke risikogrupper, tiltak rettet mot etterlatte, tiltak for kompetanseheving og økt samarbeid i hjelpeapparatet til tiltak rettet mot befolkningen som helhet. Det fremgår imidlertid av innledningen til handlingsplanen at iverksetting av nye tiltak i planperioden forutsetter at det avsettes økonomiske midler i de årlige statsbudsjettene. Det blir derfor helt avgjørende hva Regjering og Storting bestemmer seg for å satse på i årene framover. Ikke minst viktig er det at de tiltak som prioriteres, blir konkretisert og gjennomført med tilstrekkelig tyngde og forankring. Jeg vil her trekke fram fire innsatsområder hvor handlingsplanen presenterer nye tiltak med et betydelig forebyggingspotensial, og jeg vil gi eksempler på hvordan tiltakene kan utdypes: a) tiltak for å senke terskelen for å søke hjelp, b) tiltak for å fremme psykisk helse og mestring i skolen, c) tiltak for bedre tilgang til kunnskapsbasert behandling og d) tiltak for bedre monitorering av selvmordsatferd som grunnlag for evaluering og intervensjon.

\section{Senke terskelen for å søke hjelp}

Ett av tiltakene i handlingsplanen (Tiltak 14) er å utvikle strategier og tiltak for å senke terskelen for å søke helsehjelp ved psykiske plager. Planen peker på at det er behov for å prioritere innsats overfor grupper hvor forebyggingspotensialet er stort og hvor barrierene mot å søke hjelp også er store. Kombinasjonen av depresjon og selvmordsatferd hos menn nevnes spesielt. For mange menn er stigmaet forbundet med å være suicidal og bruker av psykiske helsetjenester en stor barriere mot å oppsøke hjelp.

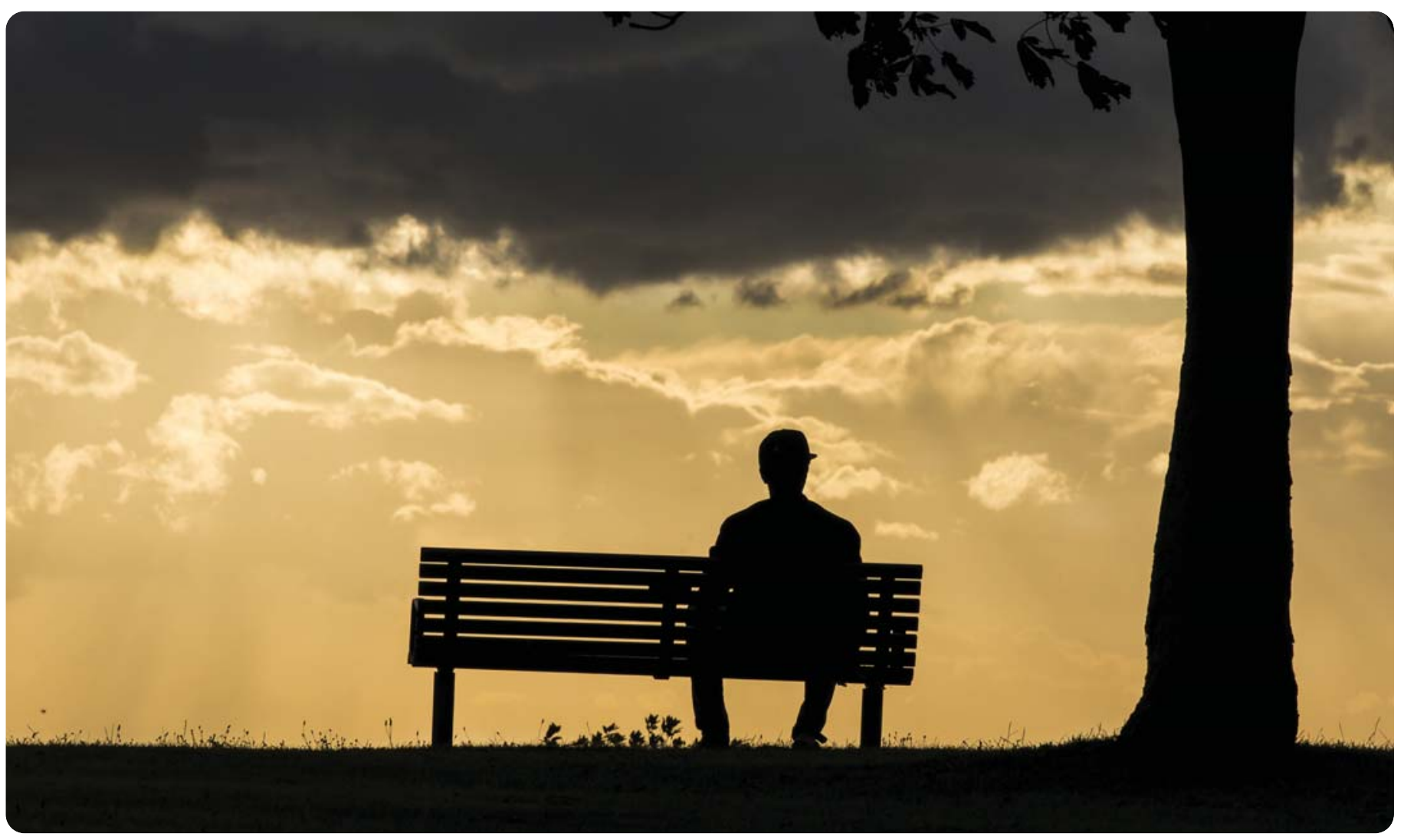




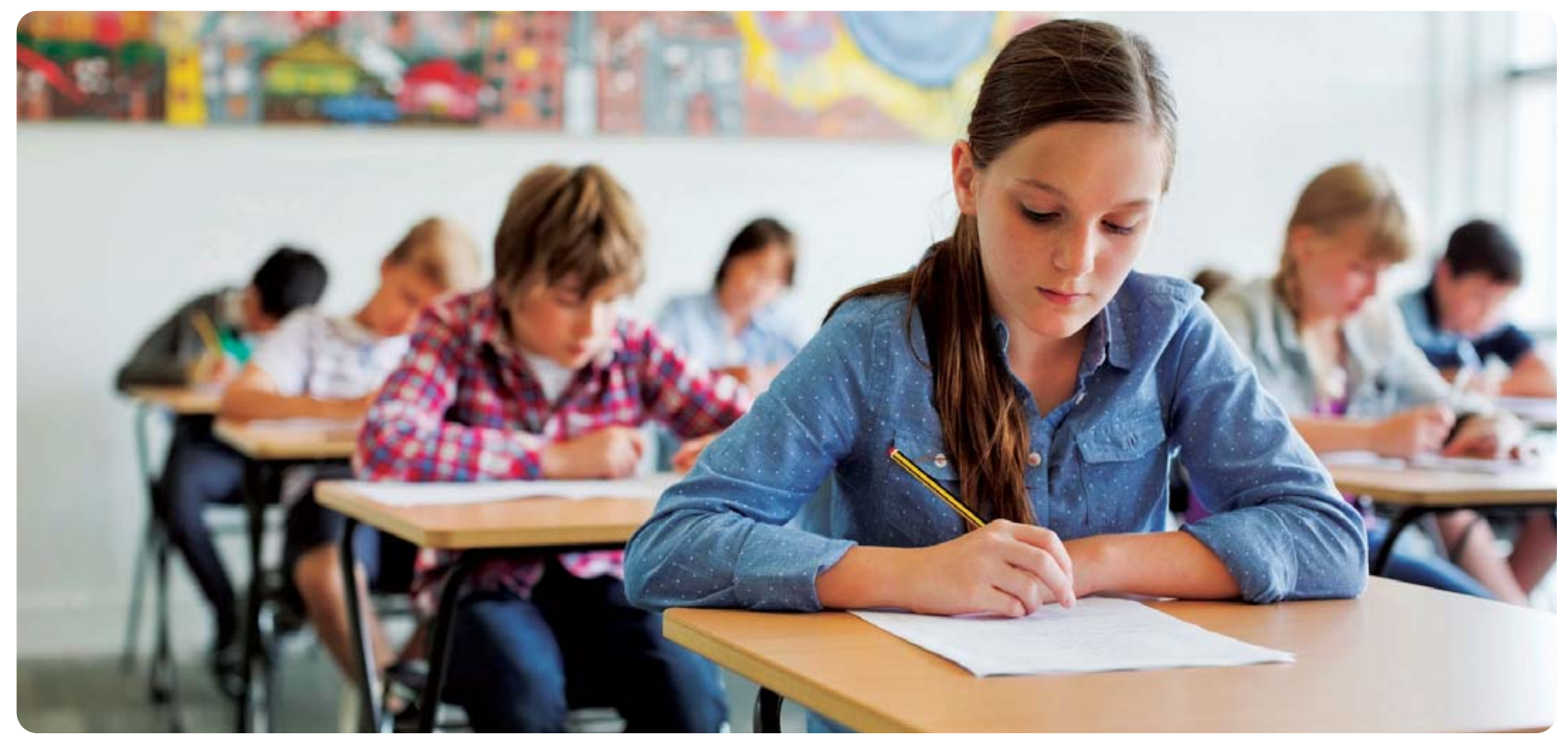

Å senke slike terskler bør imidlertid kombineres med andre tiltak, slik som å tilføre kompetanse til hjelpeapparatet slik at riktig hjelp kan bli gitt til dem som søker den. Jeg vil derfor argumentere for at dette er en gyllen anledning til å starte en satsning i Norge på en type flernivåintervensjon som man har høstet gode erfaringer med i Europa, f.eks. gjennom The European Alliance Against Depression (EAAD, www.eaad.net) (Hegerl et al., 2008). Kort oppsummert er dette en type lokal/ regional intervensjon hvor kommunikasjonsstrategier ut mot befolkningen for å redusere terskelen for å søke hjelp for selvmordsatferd og psykiske plager kombineres med økt tilgjengelighet av hjelpetjenester og samtidig kompetanseheving av nøkkelpersoner i lokalsamfunn og tjenesteapparat. En slik satsning kan tilpasses til en norsk kontekst, ta utgangspunkt i eksisterende tilbud og forankres i samarbeid mellom brukere, fagmiljø, kommunikasjonsbransje og tjenesteapparatet. En av fordelene med slike lokalt forankrede flernivåintervensjoner er at de kan bidra til spredning av kompetanse og kunnskap ut i samfunnet og tjenesteapparatet, noe som er et sentralt mål for planens Delmål 4. For eksempel er ett av de nye tiltakene i handlingsplanen å utarbeide veiledende materiell om forebygging av selvskading og selvmord for kommunene (Tiltak 20). Sjansen for at slikt materiell tas i bruk øker hvis det innføres $i$ en sammenheng hvor det oppleves relevant. Flernivåintervensjoner som EAAD kan gi en slik sammenheng. Også andre tiltak i planens Delmål 4 som omhandler kompetanseheving og rutiner for utredning og oppfølging av selvskading og selvmordsfors $ø$ (Tiltakene 21, 23-25) kan gjennom slik flernivåintervensjon få en kontekst hvor tiltak kan iverksettes og erfaringer høstes.

\section{Psykisk helse og mestring i skolen}

Det fremgår av handlingsplanen at satsingen på skolebaserte programmer skal videreføres i planperioden. I tillegg fremmes nye tiltak som blant annet har som mål å styrke skolehelsetjenesten og samarbeidet mellom skole og skolehelsetjenesten (Tiltak 1-3). Ikke minst med tanke på å nå unge menn kan forebyggende tiltak som gjennomføres i tilknytning til skolen vise seg svært viktige. Menn er en gruppe som både har en forhøyet selvmordsrisiko og som vi ofte strever med å nå med tiltak. Tiltak i skolen kan derfor være særlig viktig med tanke på å styrke unge menns livsmestringsferdigheter $\mathrm{i}$ møte med kriser. Ungdomstiden er også den tiden da flest starter med selvskading, uavhengig av kjønn. Det er derfor gode grunner til å se nærmere på en tettere integrering av psykisk helse og mestring inn i skolehverdagen. En av utfordringene med frittstående skolebaserte programmer er imidlertid den manglende kontinuitet over tid som ofte følger slike prosjektbaserte og tidsbegrensede tiltak. Dette er et argument for å gå et skritt videre og å utrede innføring av psykisk helse og mestring som et integrert obligatorisk tiltak eller fag gjennom skoleløpet. Tanken er å bygge på de erfaringene som er gjort med evaluerte programmer brukt i skolen, men samtidig sikre bedre kontinuitet. Hensikten vil være å lære barn og unge om psykisk helse og psykisk lidelse, om gode holdninger til å søke og å motta hjelp når det er nødvendig, ferdigheter $\mathrm{i}$ å mestre og å regulere følelser, og hvordan bruke disse til å løse følelsesmessige problemer. Det vil imidlertid være helt avgjørende at et slikt tiltak forankres godt i skole og skolehelsetjeneste, og at evaluering integreres i utviklingsarbeidet, siden kunnskapsgrunnlaget på dette området er begrenset. 


\section{Bedre tilgang til kunnskapsbasert behandling}

Noen grupper har behov for spesialiserte behandlingstilbud. Handlingsplanen har flere tiltak som fokuserer på dette, blant annet utprøving av et behandlingstilbud rettet mot risikoutsatt barn og ungdom i kontakt med barnevernet (Tiltak 9), utvikling av samarbeidsprosjekter om behandling av komplisert sorg (Tiltak 16) og behandling av personer med gjentatt selvmordsatferd eller selvskading. Det har lenge vært mangel på tilgang på gode behandlingstilbud for disse gruppene, ikke minst gjelder dette for ungdom med gjentatt selvskading. Det er derfor svært gledelig når kunnskapsbasert behandling for disse gruppene, også for ungdom, nå er utviklet (Mehlum et al., 2014; Shear, Ghesquiere, \& Glickman, 2013; Stoffers et al., 2012) og utdanning i behandling av komplisert sorg, selvskading og gjentatt selvmordsatferd er nå tilgjengelig i Norge. Spørsmålet er om ikke tiden også er moden for en bredere og mer konkret satsning på å gjøre behandlinger for selvskading og selvmordsatferd tilgjengelig i Norge enn det handlingsplanen legger opp til. Forholdene ligger godt til rette i og med at vi nå har en situasjon med kunnskapsbaserte behandlinger og fagmiljø som kan tilby opplæring i bruk av behandlingene.

\section{Monitorering og evaluering}

Det er særlig viktig at nye tiltak som iverksettes i forbindelse med handlingsplanen planlegges med tanke på systematisk evaluering. Manglende evaluering begrenser muligheten for å lære av tiltak, øker sjansen for at feil gjentas og kan fort føre til ineffektiv ressursbruk som blir langt mer kostbart for samfunnet over tid. I lys av dette er det en utfordring at vi mangler god oversikt over forekomst av selvskading, selvmord og selvmordsforsøk i ulike grupper av befolkningen. Mer enn 1 av 4 av de som tar sitt liv i Norge har nylig vært eller er i behandling for psykisk lidelse. Men vi har ikke god nok oversikt over utviklingen over tid og karakteristika ved disse selvmordene.
Storbritannia iverksatte for 10-15 år siden et sett av selvmordsforebyggende tiltak basert på et systematisk granskningssystem i psykisk helsevern som sannsynligvis har bidratt til en reduksjon av forekomsten av selvmord i tjenesten over tid (While et al., 2012). Det er derfor gledelig at handlingsplanen har inkludert utprøving av et slikt system som ett av de foreslåtte nye tiltak (Tiltak 29). Det er viktig at vi nå får et slikt system i Norge, slik at vi får et verktøy for å kunne avdekke svakheter ved behandlingstilbudene, lære av feil og erfaringer og kunne iverksette mer målrettede og tilpassede tiltak.

\section{Godt forankrede intervensjoner}

Det fremgår av innledningen til handlingsplandokumentet at planen kan utvides med nye tiltak i planperioden i tråd med føringer i statsbudsjettet. Planen har potensial til å bidra til å styrke forebyggingsarbeidet på viktige områder. Jeg har her forsøkt å argumentere for at noen tiltak bør prioriteres innført i større bredde og med en tydelig forankring. Jeg vil hevde at det bør satses bredt på noen nye intervensjoner som har et stort forebyggingspotensial og/eller som har et godt kunnskapsgrunnlag. Det blir altså helt avgjørende hvor tungt og med hvilke ressurser det satses i planperioden. Den første testen på hvilken retning dette kommer til å gå, får vi i forbindelse med fremlegget og behandlingen av statsbudsjettet for 2015. Sett i lys av dette har vi som arbeider med forskning og forebygging en viktig oppgave som aktive premissleverandører både i diskusjonen rundt prioriteringer og i arbeidet med å bidra til effektiv implementering av tiltak i tiden fremover.

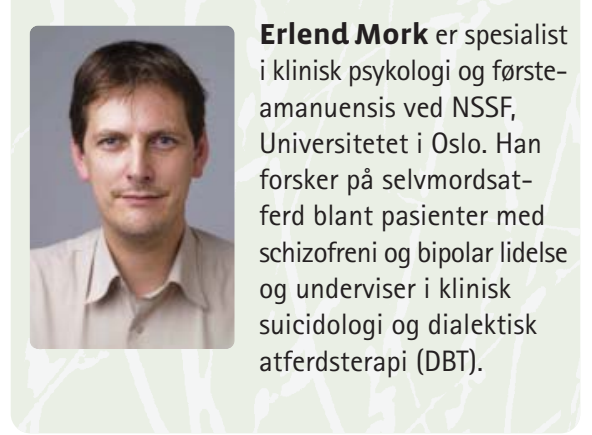

\section{Referanser}

Hegerl, U., Wittmann, M., Arensman, E., Van Audenhove, C., Bouleau, J. H., Van Der Feltz-Cornelis, C., Pfeiffer-Gerschel, T. (2008). The 'European Alliance Against Depression (EAAD)': a multifaceted, community-based action programme against depression and suicidality. World Journal of Biological Psychiatry, 9(1), 51-58. doi: 10.1080/ 15622970701216681

Helsedirektoratet. (1993) Nasjonalt program for forebygging av selvmord i Norge. Helsedirektoratets utredningsserie 1-93. IK-2388. Oslo: Helsedirektoratet.

Helsedirektoratet. (2014) Handlingsplan for forebygging av selvmord og selvskading 2014-2017. IS-2182. Oslo: Helsedirektoratet.

Mehlum, L., Tørmoen, A. J., Ramberg, M., Haga, E., Diep, L. M., Laberg, S., Grøholt, B. (2014). Dialectical Behavior Therapy for Adolescents With Repeated Suicidal and Self-harming Behavior - A Randomized Trial. Journal of the American Academy of Child and Adolescent Psychiatry.

Muehlenkamp, J. J., Claes, L., Havertape, L., \& Plener, P. L. (2012). International prevalence of adolescent non-suicidal self-injury and deliberate self-harm. Child Adolesc Psychiatry Ment Health, 6, 10. doi: 10.1186/1753-2000-6-10

Reinholdt, N. P. (2000). Oppfølgingsprosjekt Tiltak mot selvmord 2000-2002. Suicidologi, 5(3), 14.

Shear, M. K., Ghesquiere, A., \&t Glickman, K. (2013). Bereavement and complicated grief. Curr Psychiatry Rep, 15(11), 406. doi: 10.1007/s11920-013-0406-z

Statens helsetilsyn. (1995) Prosjektplan og handlingsplan mot selvmord 1994-1998. Skriftserie 4-95. Oslo: Statens helsetilsyn.

Stoffers, J. M., Völlm, B. A., Rucker, G., Timmer, A., Huband, N., \&t Lieb, K. (2012). Psychological therapies for people with borderline personality disorder. Cochrane Database Syst Rev, 8, CD005652. doi: 10.1002/14651858.CD005652.pub2

Tormoen, A. J., Rossow, I., Larsson, B., \&t Mehlum, L. (2012). Nonsuicidal self-harm and suicide attempts in adolescents: differences in kind or in degree? Social Psychiatry and Psychiatric Epidemiology. doi: 10.1007/s00127-012-0646-y

While, D., Bickley, H., Roscoe, A., Windfuhr, K., Rahman, S., Shaw, J., Kapur, N. (2012). Implementation of mental health service recommendations in England and Wales and suicide rates, 19972006: a cross-sectional and before-and-after observational study. Lancet, 379(9820), 1005-1012. doi: 10.1016/s0140-6736(11)61712-1 